\title{
Flash Flood Management Approach for Flood Risk Areas Using Numerical Climate Modeling Data Analysis
}

\section{Md. Altaf Hossain}

Sylhet Agricultural University

\section{Fahmida Ishaque}

Sylhet Agricultural University

MD HAFIZUR RAHMAN ( $\nabla$ miltonrumc@gmail.com )

Sylhet Agricultural University

\section{Gazi Tamiz Uddin}

Sylhet Agricultural University

\section{Md. Abdur Rashid Sarker}

Sylhet Agricultural University

\section{Joyshankar Baidya}

Sylhet Agricultural University

Israt Jahan Ripa

Sylhet Agricultural University

\section{Research}

Keywords: Flash flood, Boro rice, Numerical Climate Modeling, Risk analysis, Mann-Kendall test, Strategy development

Posted Date: July 16th, 2020

DOI: https://doi.org/10.21203/rs.3.rs-43740/v1

License: (c) (1) This work is licensed under a Creative Commons Attribution 4.0 International License. Read Full License 


\title{
Flash flood management approach for flood risk areas using numerical climate modeling data analysis
}

\author{
Md. Altaf Hossain ${ }^{1}$, Md. Hafizur Rahman ${ }^{1 \dagger}$, Fahmida Ishaque ${ }^{1}$, Gazi Tamiz Uddin ${ }^{1}$, Md. Abdur Rashid \\ Sarker ${ }^{1}$, Joyshankar Baidya ${ }^{1}$, Israt Jahan Ripa ${ }^{1}$
}

\begin{abstract}
${ }^{1}$ Department of Agricultural Construction and Environmental Engineering, Sylhet Agricultural University, Sylhet-3100, Bangladesh.
\end{abstract}

${ }^{\dagger}$ Corresponding Author: miltonrumc@gmail.com

\begin{abstract}
The present study measures management of flash flood to avoid the devastating impacts on boro rice production at Sunamganj district. This study interacts for meteorological parameter assessment with global climate data. Three major climatic parameters (precipitation, temperature and cloud fraction) have been considered for this study. These three climatic data were analyzed using numerical software EdGCM for the period 1920 to 2020 and then downscaled by Transform software. Flash floods have been classified as general flash floods and devastating flash flood. Flash floods have been reported to be severe in March and April. A trend was evaluated for the detection of flash flooding occurrences. The study concludes that when temperature is high, a small amount of rainfall can cause a slight cloud fraction to cause flooding. Flash flooding occurs when temperature is above $76^{\circ} \mathrm{F}\left(24.44^{\circ} \mathrm{C}\right)$, rainfall is at least $3 \mathrm{~mm}$ and cloud fraction is at most $46 \%$. Furthermore, for validation Mann-Kendall trend analysis have been done. The test result discovered increasing trend for rainfall and decreasing trend for temperature and cloud fraction. Finally, an algorithm was developed in $\mathrm{C}_{++}$program as a flash flood precaution tool which helped to prepare strategy as well as to adapt with the flash flood.
\end{abstract}

Keywords: Flash flood, Boro rice, Numerical Climate Modeling, Risk analysis, Mann-Kendall test, Strategy development.

Introduction

Flash floods arise from intense storms dropping large amounts of rain within a short duration with little or no warning. The occurrence of flash flooding is of concern in hydrologic and natural hazards science due to the top ranking of such events among natural disasters in terms of both the number of people affected globally and the proportion of individual fatalities (Borga, 2011). A flash flood or a rapid onset flood refers to short duration flooding with a comparatively high peak discharge of water in a particular place. Flash flood occurs within a few hours of heavy rainfall, rapid snowmelt or after a sudden glacier lake outburst or embankment failure or very rapid break up of an ice block which is due to rapid increase in temperature. Flash flood stimulates shortly after sever rainfalls reaching up to $100 \mathrm{~mm}$ within 6 hours and extreme flow of high water and normally occur in small dry valleys. In the flash flood events unexpected increase in water close in streams and rivers and very high flow speed bring large amount of debris, boulders, uprooted trees, obliteration of infrastructures and constructed buildings stand in its path. (Hill,2010). The frequency of natural disasters has been increasing over the years, resulting in loss of life, damage to property and destruction of the environment (Living with Risk, 2000).

Agriculture is a risky business in Bangladesh. Crop production of farmers is badly affected by a diverse range of risks (Swanson, 2008). Flood is part and parcel of living for a large number of people in Asia and the Pacific. It is a regular phenomenon particularly in such countries as Bangladesh, Myanmar, Thailand, India, Vietnam and Cambodia, where the loss of human lives, natural resources, crops and livestock have at times destroyed the financial backbone of farmers. There are about 31 million hectares of flood-prone areas in South and South East Asia, of which 13 million are used for agriculture, mainly for the planting of some form of deep-water rice 
(Singh, et. al. 2001). In the haor areas of North-Eastern region, flood caused wide ranging damage of Boro crop, during the August flood, some areas were newly inundated after a long period and the two floods in spite of their distinctive features, have caused significant damage to affected areas. Damage was incurred in the form of: Loss of lives, dwelling houses and livelihood, crop damage and physical infrastructure damage. CPD has estimated the loss of Boro rice production to be to the tune to 15.8 lac MT. The loss is equivalent to $8.3 \%$ of national average of Boro production. This is about 52.2\% of total Boro rice production of the concerned six districts. (CPD,2007). Haors with their unique hydro-ecological characteristics are large bowl-shaped floodplain depressions located in the north-eastern region of Bangladesh in Sunamganj, Sylhet, Moulvibazar, Kishoreganj, Habiganj, Brahmanbaria, and Netrokona districts (CEGIS, 2012). Almost $80 \%$ of the haor area is covered by boro rice which is the main crop and is frequently affected by the flash floods in the pre-monsoon months of April and May (Khan et al., 2012). The concept of risk assessment needs to be changed to include such measures as adaptation strategies and to recognize not only the role of geography, or location, but to also recognize socially constructed vulnerability (Chang $\mathrm{CH}, 2011$ ). Along with risk assessment there is also the issue of risk reduction, which is often limited in terms of funding and resources, but it is important to achieve it through awareness, education, dissemination, and community preparedness and to keep it in mind during health system planning (Few R, 2004). Adaptation is the principal way to deal with the unavoidable impacts of climate change. It is a mechanism to manage risks, adjust economic activity to reduce vulnerability and to improve business certainty (Governments, C. 2007). The framework for the formulation of a realistic strategy for adaptation to future floods was outlined and can be implemented in five, universally applicable, steps. These are: Flood risk assessment, building the scenarios of adaptation, scenario choice, analysis of legislative instruments and implementation. There are many gaps in the research that has been conducted on flash flood, including gaps in crop production, as well as the gaps in understanding how we can reduce the implications of climate change, which plays a significant role in the presence of natural disasters, especially floods. In terms of Boro production during floods, further research needs to be conducted to determine the appropriate variety of Boro Crop. Little research has been done to examine long-term health implications, even in high-income countries. This research would be important in order to learn how to provide counseling and continued care long after a flood has occurred. Mortality risks and risks of infectious disease also require research, as there is hardly any quantifiable research in this area.

Further research is also needed to determine to what extent climatic parameter adds to flash flood risks assessment and to develop a precaution strategy.

Objective of the study was

- To develop a formulation framework and precaution strategy about flash flood.

- To develop a suitable cropping pattern for the study area.

\section{Materials and methods}

\section{Study area}

This research has been conducted at the haor areas of Sunamganj district in the Sylhet division. Shown in Fig.1. 


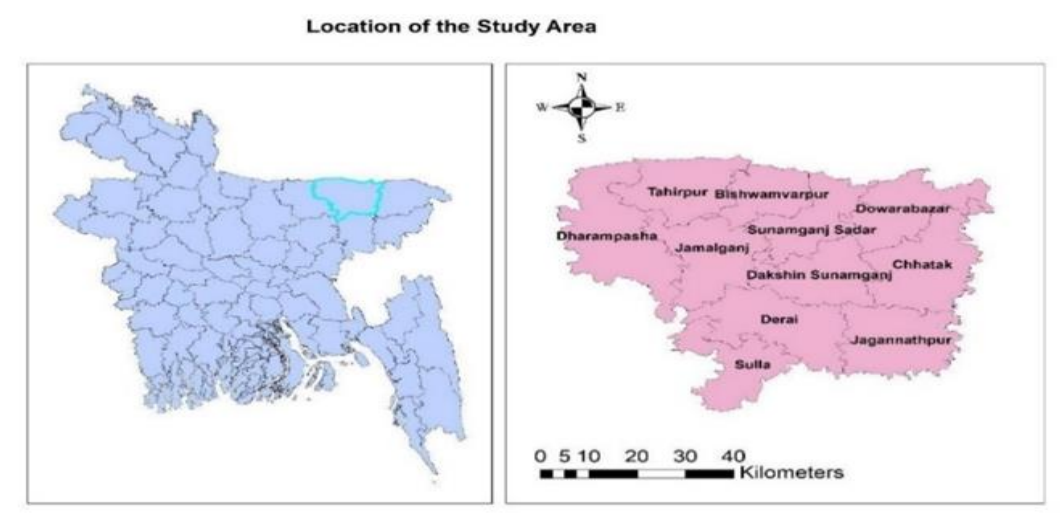

Fig. 1. Study Area

Sunamganj District (sylhet division) area 3,669.58 sq km, located in between $24^{\circ} 34^{\prime}$ and $25^{\circ} 12^{\prime}$ north latitudes and in between $90^{\circ} 56^{\prime}$ and $91^{\circ} 49^{\prime}$ east longitudes. It is bounded by Meghalaya state of India on the north, habiganj and kishoreganj districts on the south, sylhet district on the east, netrokona district on the west ( Banglapedia)

\section{Data Collection}

Rainfall, temperature and cloud fraction data was considered for this study. 100 years' data of temperature, rainfall and cloud fraction was obtained from Educational Global Climate Model (EdGCM) software and then converted these data into regional/local scale by using Transform software.

\section{Extracting data from EdGCM}

At first data was generated by using the EdGCM software. EdGCM stands for Educational Global Climate Model. EdGCM, an integrated software suite designed to simplify the process of setting up, running, analyzing and reporting on global climate model simulations. Almost 100 years of data was generated for the parameter of Cloud fraction, Rainfall and Temperature. The data generated from EdGCM is in global format. To convert these data into regional scale Transform software was used. Transform software is a software that is used for statistical downscaling of global data into local data which is then used for climate modeling data analysis. Data extracting procedure was shown in Fig.2. 


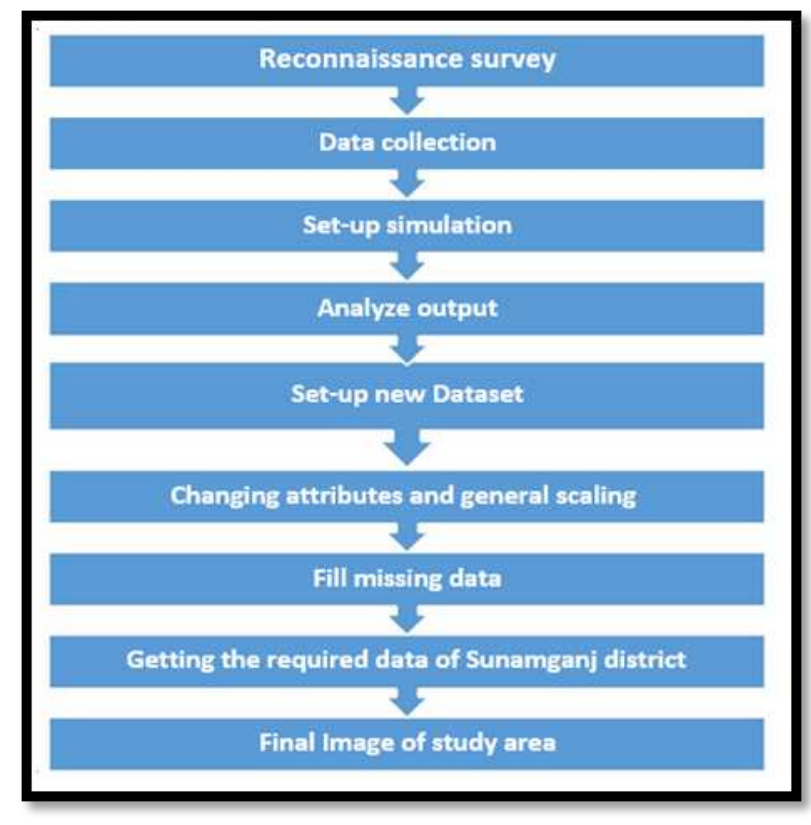

Fig.2. Data Extracting procedure from EdGCM

\section{Results and Discussion}

Risk is completely associated with uncertainty and damage. Symbolically, it can be present as:

Risk $=$ Uncertainty + Damage.

Risk can be defined as the probability of loss; it depends on vulnerability, hazard and exposure. "Risk (i.e. 'total risk') means the expected number of lives lost, persons injured, damage to property and disruption of economic activity due to a particular natural phenomenon, and consequently the product of specific risk and elements at risk". Total risk can be measured as:

Risk $($ total $)=$ Hazard $($ Elements at Risk $)+$ Vulnerability.

Risk and vulnerability are related to each other. Vulnerability is the plight of a commodity, system or asset that makes it susceptible to damage in the face of a hazard. Hazard on the other hand, is an unavoidable event that brings dangers.

The framework for flood risk management begins with the definition of 'flood risk'. There is no single definition for flood risk but the one that is very useful to start from says that flood risk is unity of hazard, exposure and vulnerability (Kron, 2005).

\section{EdGCM trend analysis}

The trend is made using temperature, precipitation, and cloud fraction data. EdGCM and Transform software were used to generate global and downscaled data for Sunamganj district. Generally, normal flash floods occur in Sunamganj all year long, but in July to October, a high percentage of flash floods occur. According to data analyzed between 1920 and 2018, it was found that when the floods occurred in March and April, they became destructive in nature and in that time the flood situation, temperature, rainfall and cloud fraction were noted intemperature minimum $76^{\circ} \mathrm{F}\left(\geq 76^{\circ} \mathrm{F}\right)$, rainfall minimum $3 \mathrm{~mm}(\geq 3 \mathrm{~mm})$ and cloud fraction maximum $46 \%(\leq 46$ $\%)$.

\section{Trend analysis of Sunamganj district}

Covering all three parameters in the graph helps to have a clearer picture of the interdependence of these parameters. The green, blue, and red lines indicate the fraction of clouds, rainfall, and temperature, respectively. 
The green dots in the red line indicate flash floods. In fact, most of the temperatures are on the higher side during flash floods as the green dots coincide with the crest of the temperature line. Trend analysis of Sunamganj district step by step (1920-2020) was shown in Fig.3.
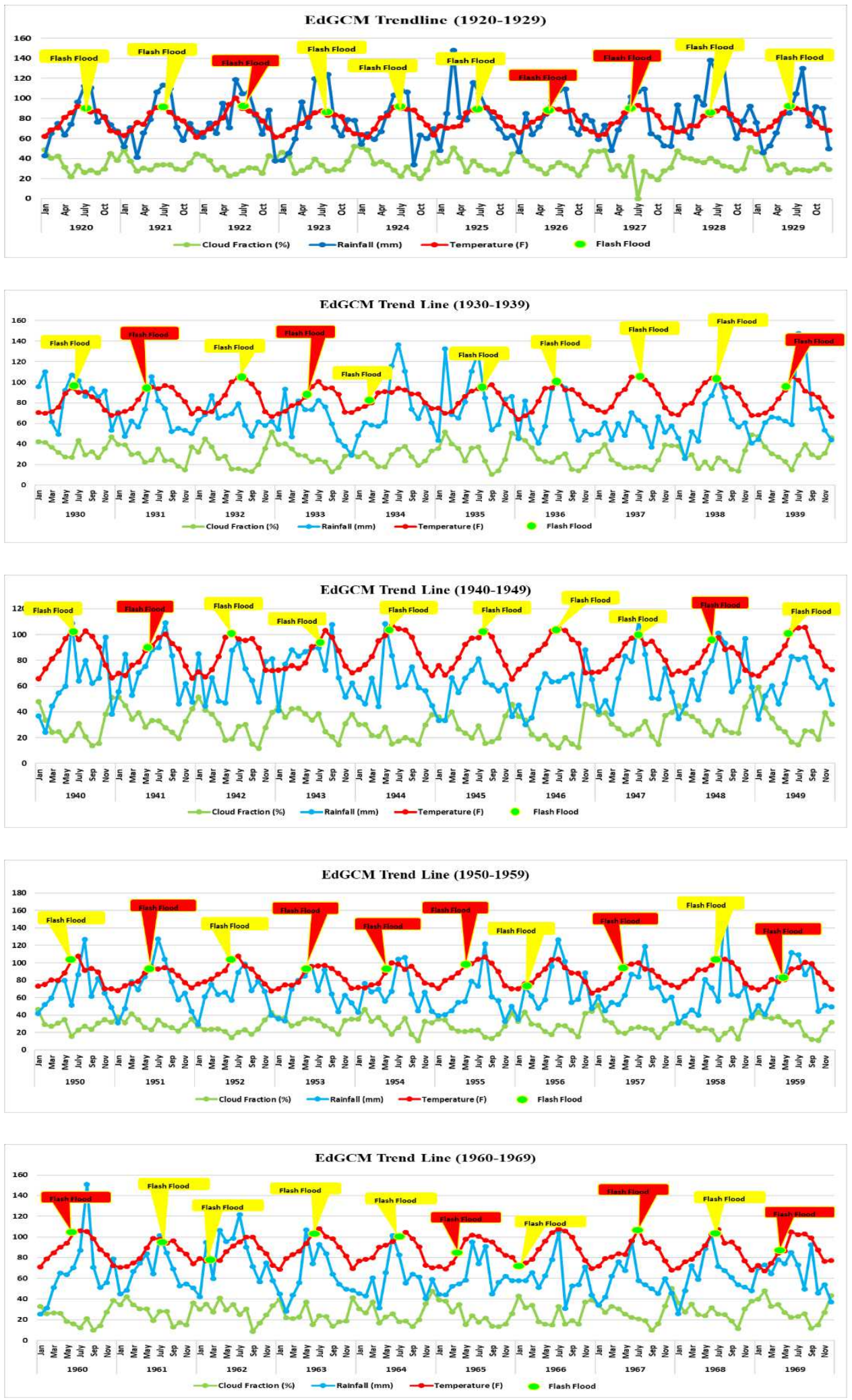

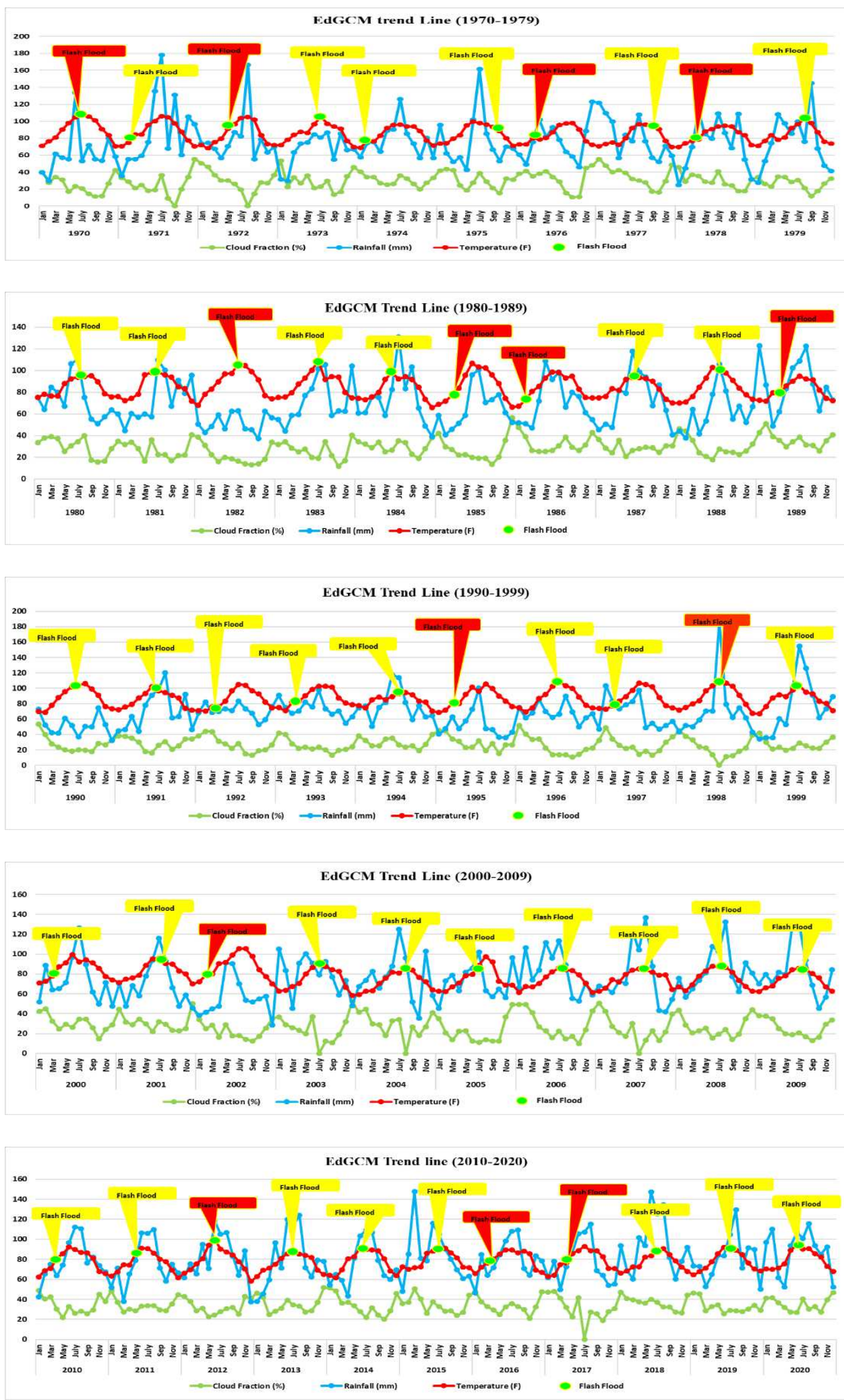

Fig. 3. Flash flood trend of Sunamganj district from 1920-2020

The devastating and non-devastating flash flooding year in the study area was shown in Table 1.

Table 1. Devastating and Non-devastating flash flood 


\begin{tabular}{|l|l|}
\hline Name of flash flood & Year \\
\hline Devastating & $1922,1926,1927,1931,1933,1939,1941,1948,1951,1953,1954$, \\
& $1955,1957,1959,1960,1965,1969,1970,1972,1976,1978,1982$, \\
& $1985,1986,1989,1995,1998,2002,2012,2016,2017$. \\
\hline Non-devastating & $1920,1921,1923-1925,1928,1929,1930,1932,1934-1938,1940$, \\
& $1942-1947,1949,1950,1952,1956,1958,1961-1964,1966-1968$, \\
& $1971,1973-1975,1977,1979-1981,1983,1984,1987,1988,1990-$ \\
& $1994,1996,1997,1999-2001,2003-2011,2013-2015,2018-2020$. \\
\hline
\end{tabular}

\section{Mann-Kendall Z test for climatic parameters}

Mann-Kendall trend test (Mann,1945) and (Kendall, 1976) which is one of the widely used (Basistha A et, al.2009, Oguntunde PG, et, al 2012) non-parametric tests to detect significant trends in time series is used in the present study. The Mann-Kendall trend test, being a function of the ranks of the observations rather than their actual values, is not affected by the actual distribution of the data and is less sensitive to outliers.

The results of Mann-Kendall $\mathrm{Z}$ test for 100 years were shown in Table 2.

Table 2. Results of Mann-Kendall Z test for 100 years (1921-2020) annual trend.

\begin{tabular}{|l|l|l|l|}
\hline & TEMPERATURE & RAINFALL & CLOUD FRACTION \\
\hline Time series & Annual & Annual & Annual \\
\hline First year & 1920 & 1920 & 1920 \\
\hline Last year & 2020 & 2020 & 2020 \\
\hline No. of observations & 100 & 100 & 100 \\
\hline Test Z & -0.71 & 2.60 & -0.68 \\
\hline Trend & Decreasing (declining) & Increasing (inclining) & Decreasing (declining) \\
\hline Significance & + & $\star *$ & + \\
\hline Sen's slope (Q) & -0.012 & 0.006 & -0.010 \\
\hline
\end{tabular}

Sen's slope estimator for climatic parameters

Trend of climatic parameters over the study period of 100 years were shown in Table 3.

Table 3. Trends of climatic parameters over the study period (1921-2020).

\begin{tabular}{|l|l|l|l|}
\hline & TEMPERATURE & RAINFALL & CLOUD FRACTION \\
\hline Sen's slope $(Q)$ & -0.012 & 0.006 & -0.010 \\
\hline
\end{tabular}

Three different trends of temperature, rainfall and cloud fraction for 100 years was shown in Fig.4.
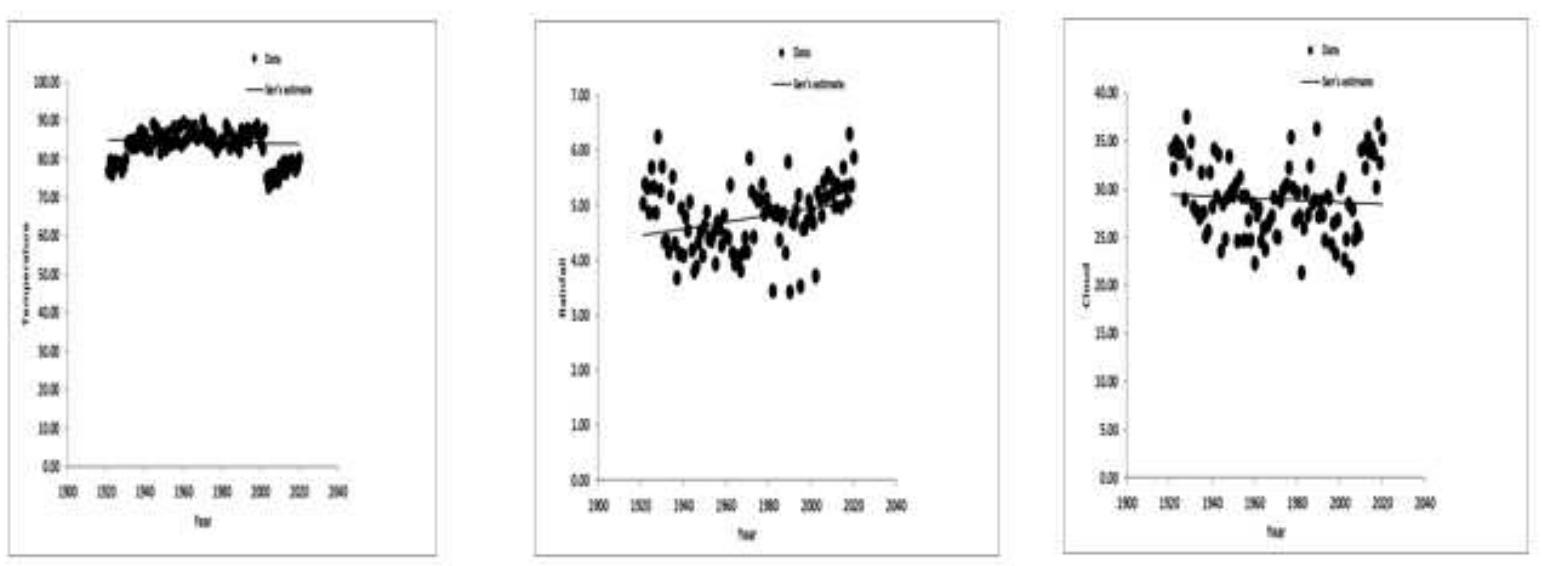

Fig.4. Trend of climatic parameters (temperature, precipitation and cloud fraction) for 100 years

\section{Adaptation Framework}


Flash Flood precaution tool was developed using $\mathrm{C}++$ programme. The algorithm was developed to detect early or late flash flood.

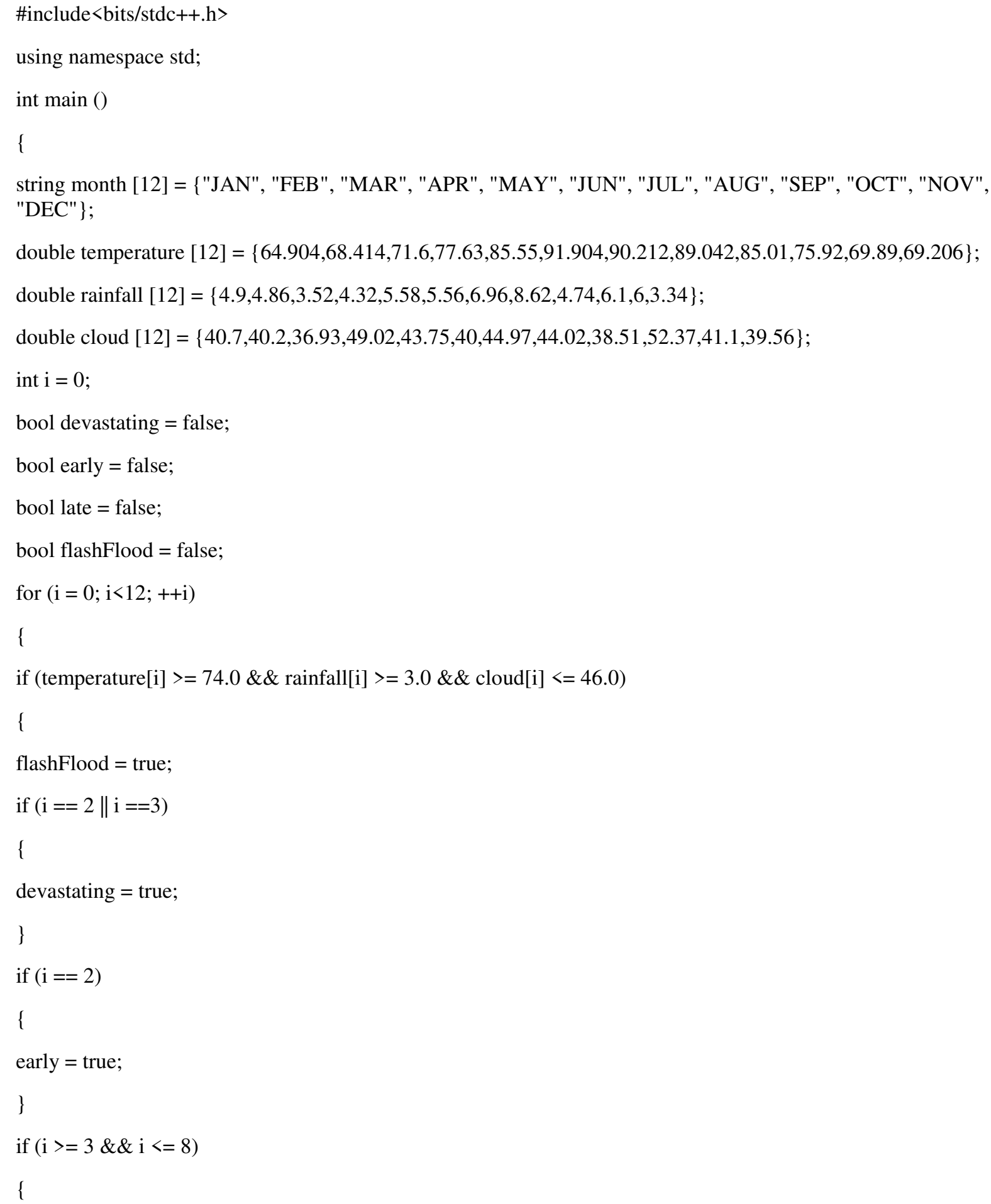




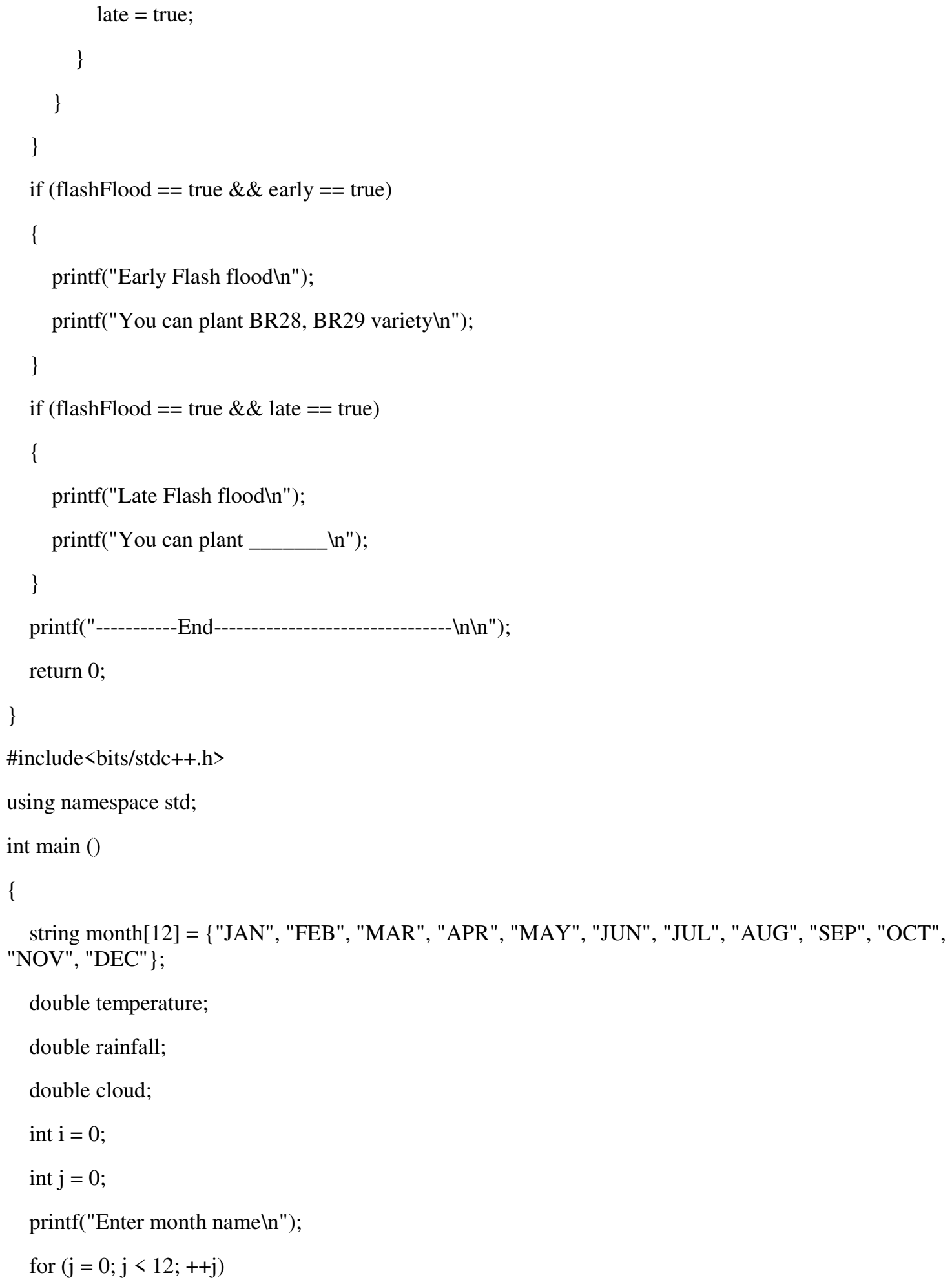




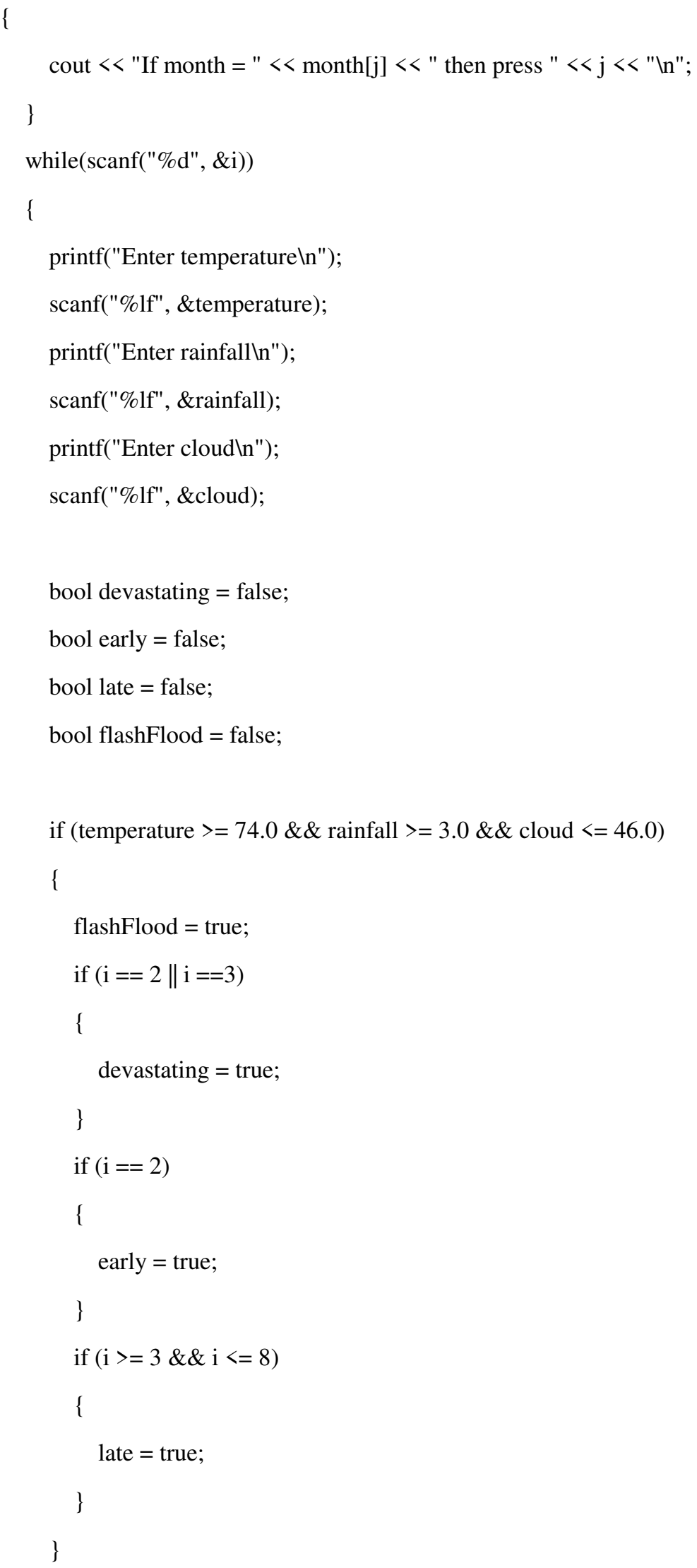




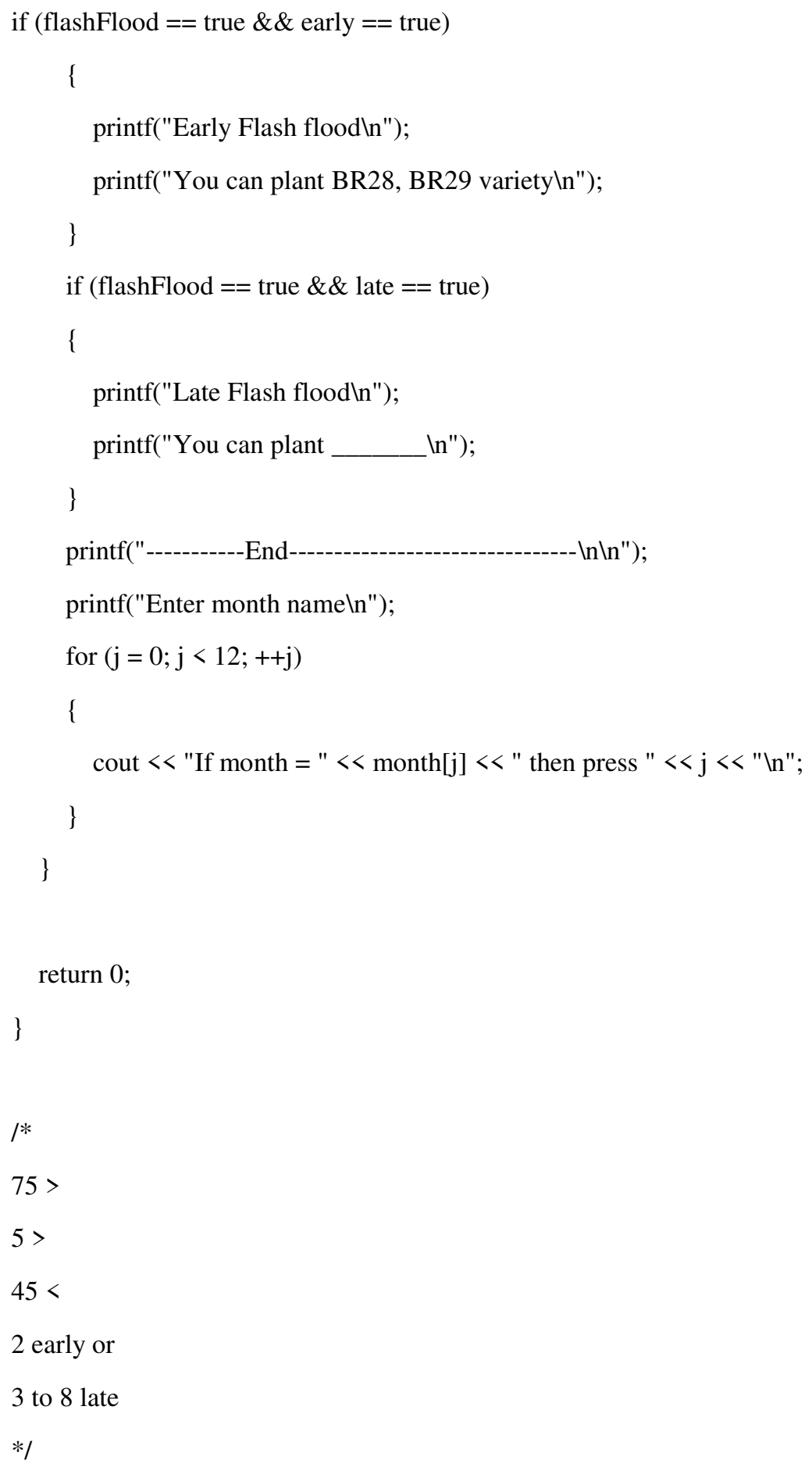


Enter month name

If month $=$ JAN then press $\theta$

If month $=$ FEB then press 1

If month = MAR then press 2

If month $=$ APR then press 3

If month = MAY then press 4

If month $=$ JUN then press 5

If month $=$ JUL then press 6

If month = AUG then press 7

If month = SEP then press 8

If month $=$ OCT then press 9

If month $=$ NOV then press 10

If month $=$ DEC then press 11

2

Enter temperature

75

Enter rainfall

5

Enter cloud

40

Early Flash flood

You can plant BR28, BR29 variety

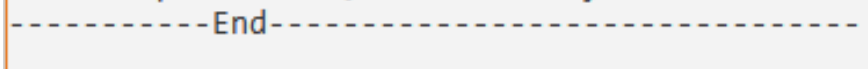

Enter month name

If month $=$ JAN then press $\theta$

If month = FEB then press 1

If month = MAR then press 2

If month $=$ APR then press 3

If month = MAY then press 4

If month $=$ JUN then press 5

If month $=$ JUL then press 6

If month = AUG then press 7

If month $=$ SEP then press 8

If month $=$ OCT then press 9

If month $=$ NOV then press 10

If month $=$ DEC then press 11

3

Enter temperature

75

Enter rainfall

7

Enter cloud

5

Late Flash flood

You can plant

Y........... End-

Enter month name

If month $=$ JAN then press $\theta$

If month = FEB then press 1

If month = MAR then press 2

If month $=$ APR then press 3 


\section{Formulation of Precautions Strategy}

A precaution strategy cycle was shown in Fig.5.

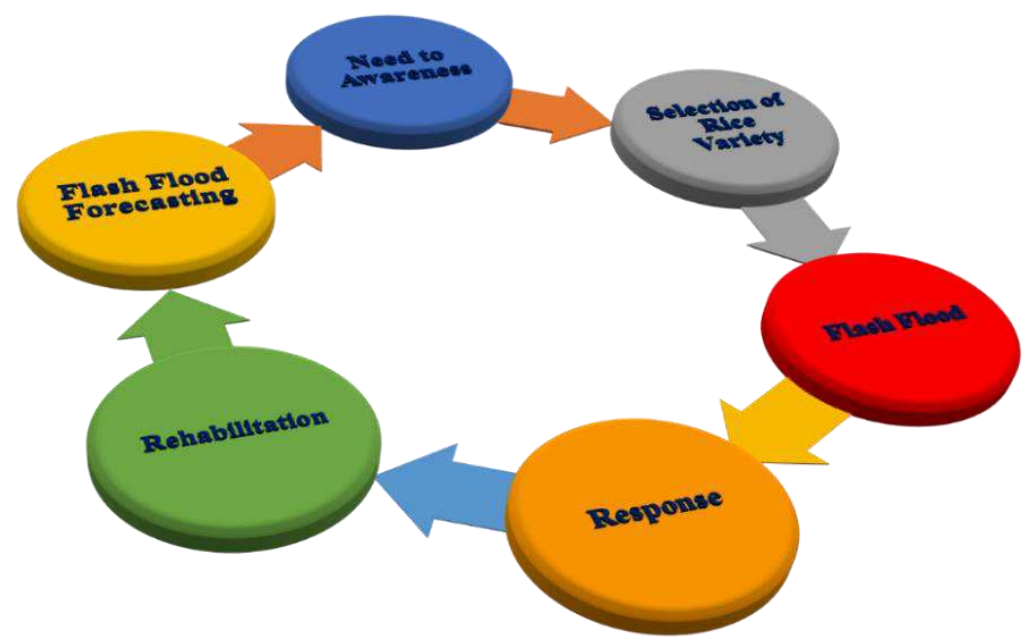

Fig. 5. Precautions Strategy Cycle

\section{Flash Flood Forecast}

- Flash flood trend should be developed before Boro season.

- Trend value should be input in develop flash flood precaution tool (in developed algorithm) for variety selection and decision making.

\section{Need to Awareness}

- Develop Community based organization.

- DAE and NGO Personnel

- SMS through Smart Phone.

\section{Selection of Rice Variety}

- Bangladesh Rice Research Institute (BRRI) developed rice variety.

- Department of Agricultural Extension (DAE) suggested variety

- Bangladesh Agricultural Research Council (BARC) recommended variety.

\section{Flash Flood}

- If flash flood occurs, then -

\section{Response}

- Rescue efforts

- First aid treatment

- Monitoring of secondary disaster

- Construction of temporary housing

- Establishment of tent villages

\section{Rehabilitation}

- Disaster resistant reconstruction

- Appropriate land use planning

- Livelihood support 


\section{Conclusion}

This study approaches for identifying the meteorological factors that contribute to the occurring flash flood with global climate data and its impacts to local scale data. To attain the objective of the study three climatic parameters were selected. As early flash flood season in Bangladesh has saturated upper soil crust, so the precipitation directly transforms to runoff then converted to flood. So, the other parameters relating so soil do not consider for the study. The analysis of temperature, rainfall and cloud fraction have been done for Sunamganj district to detect flash flood during the period of 1920 to 2020. The data of temperature, rainfall and cloud fraction was generated by using EdGCM and then downscaled into local data by using Transform software. By analyzing it was found that when the temperature is minimum $76^{\circ} \mathrm{F}$, rainfall is minimum $3 \mathrm{~mm}$ and the cloud fraction is maximum $46 \%$ then flash flood occurs. There is flash flood all the year around but it was also found that when flash flood hits in the month of March and April then it is more devastating in nature.

Based on the current study some potential recommendation can be made as follows:

1. The study was based on simulated data, further study should be done based on real time data to understand the situation in true manner.

2. The current study considered only three climatic parameters; more climatic parameters should be included to evaluate the trend.

3. A robust forecasting system could be developed to predict future flash flood years to take precautionary measures to reduce production loss.

4. Trend can also be developed for the other flash flood prone areas in Bangladesh.

\section{Abbreviations}

EdGCM: Educational global climate modeling

\section{Acknowledgements}

It is pleased to acknowledge National Agricultural Technology Program-Phase II Project (NATP-2), Bangladesh Agricultural Research Council (BARC) for granting fund by which the research work was conducted.

\section{Authors' Contribution}

The corresponding author collects and analyzes the data, and wrote the manuscript. All authors read, edit and approved the manuscript.

\section{Authors' information}

N/A

\section{Funding}

This work was supported by the National Agricultural Technology Program-Phase II Project (NATP-2), Bangladesh Agricultural Research Council (BARC).

\section{Availability of data and materials}

The data will be available at the department of Agricultural Construction and Environmental Engineering, Sylhet Agricultural University, Sylhet-3100, Bangladesh.

\section{Consent for publication}

All the co-authors consented for the publication

\section{Competing interests}

There is no competing interest.

\section{References}

Borga M, Anagnostou EN, Blöschl G, Creutin JD (2011) Flash flood forecasting, warning and risk management: the HYDRATE project. Environmental Science \& Policy. 14(7): 834-844.

Hill C, Verjee F, Barrett C. (2010) Flash flood early warning system reference guide. University Corporation for Atmospheric Research. Boulder, CO, USA. 
Swanson BE (2008) Global review of good agricultural extension and advisory service practices. Rome: Food and Agriculture Organization of the United Nations.

Singh VP, Singh RK (2000) Rainfed rice: a sourcebook of best practices and strategies in eastern India.

Sadique MZ. Flood (2017) Assessing Damage and Post-Flood Management.

Sourav A, Abdullah M (2017) Impact of flash flood on boro rice production in Taherpur upazila.

Khan MNH, Mia MY, Hossain MR (2012) Impacts of flood on crop production in Haor areas of two Upazillas in Kishoregonj. Journal of Environmental Science and Natural Resources. 5(1): 193-198.

Chang $\mathrm{CH}$ (2011) Preparedness and storm hazards in a global warming world: lessons from Southeast Asia. Natural hazards. 56(3): 667-679.

Few R, Ahern M, Matthies F, Kovats S (2004) Floods, health and climate change: a strategic review.

Governments c. National Climate Change Adaptation Framework. Australian Government,Canberra (2007) Available from: https://www.nccarf.edu.au/sites/default/files/Australian-Government-2007a.pdf

Hirsch RM, Slack JR., Smith RA (1982) Techniques of trend analysis for monthly water quality data. Water resources research. 18(1): 107-121.

Banglapedia. Available from: http://en.banglapedia.org/index.php?title=Sunamganj_District

Kron W (2005) Flood risk= hazard $\times$ values $\times$ vulnerability. Water International. 30(1), 58-68.

Basistha A, Arya DS, Goel NK (2009) Analysis of historical changes in rainfall in the Indian Himalayas. Int. J. Climatol. 29:555-572.

Oguntunde PG, Abiodun BJ, Olukunle OJ, Olufayo AA (2012) Trends and variability in pan evaporation and other climatic variables at Ibadan, Nigeria, 1973-2008. Meteorological Applications. 19(4): 464-472. 
Figures

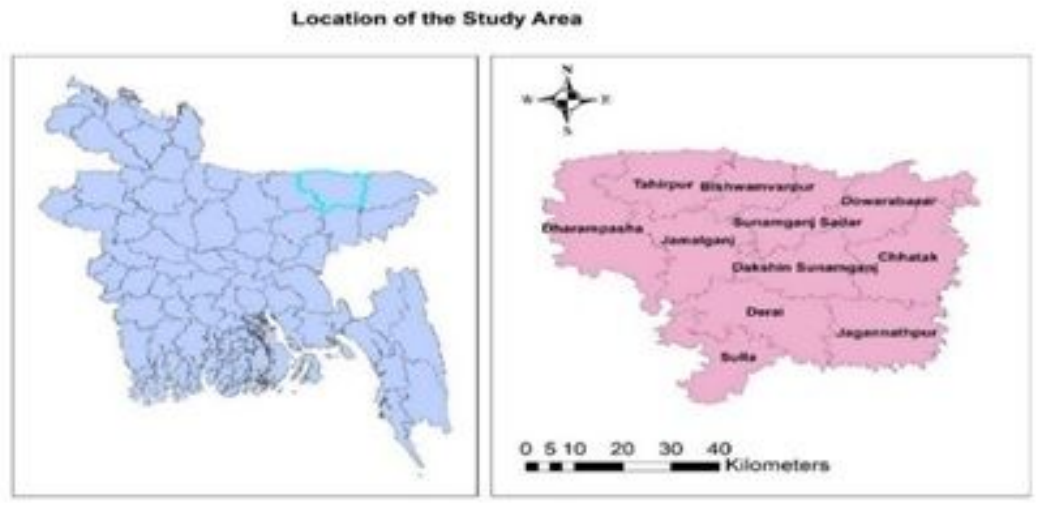

Figure 1

Study Area

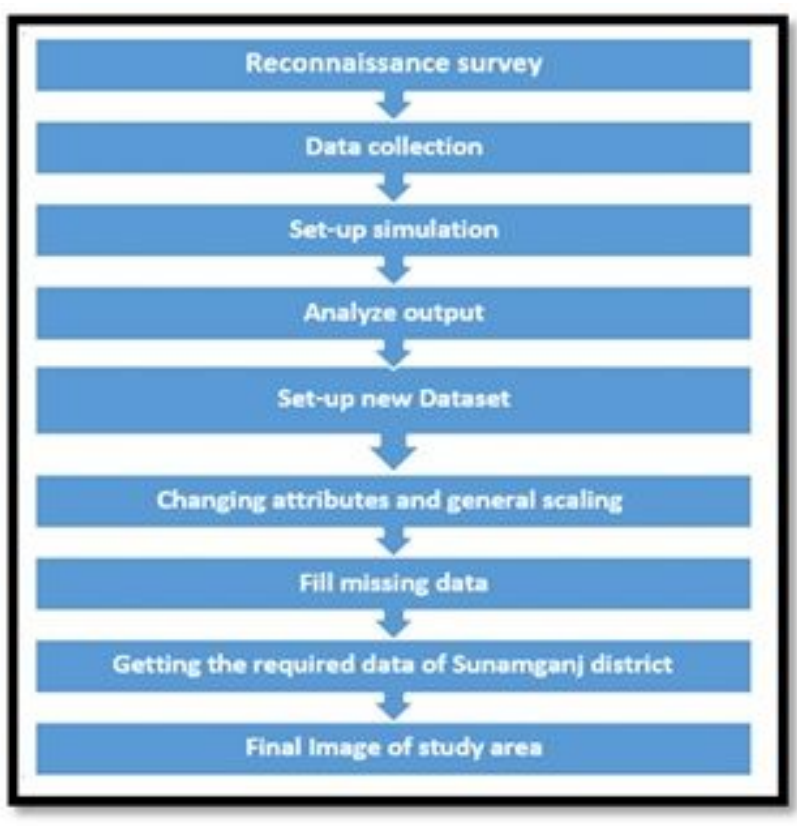

Figure 2

Data Extracting procedure from EdGCM 

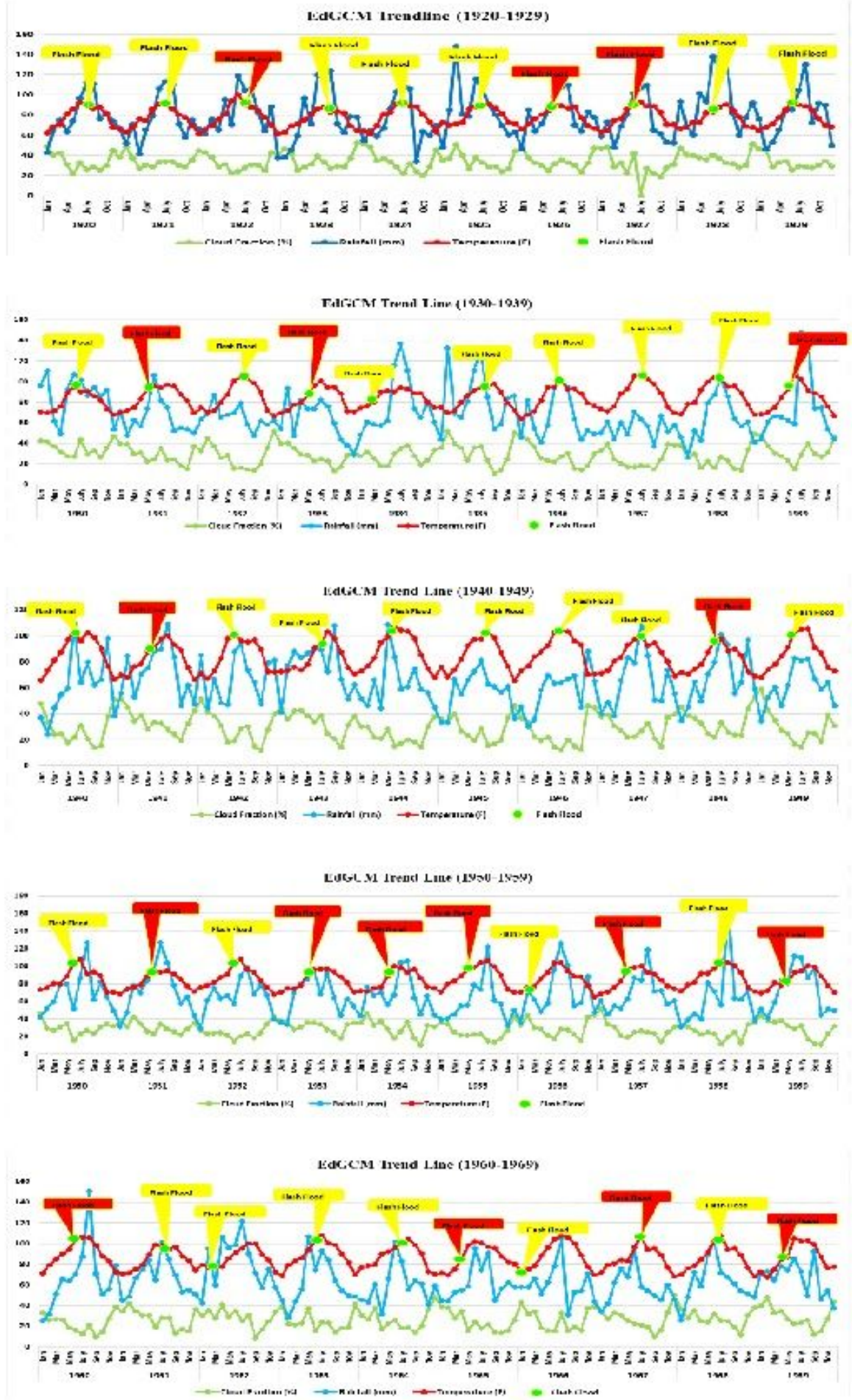

\section{Figure 3}

Flash flood trend of Sunamganj district from 1920-2020 

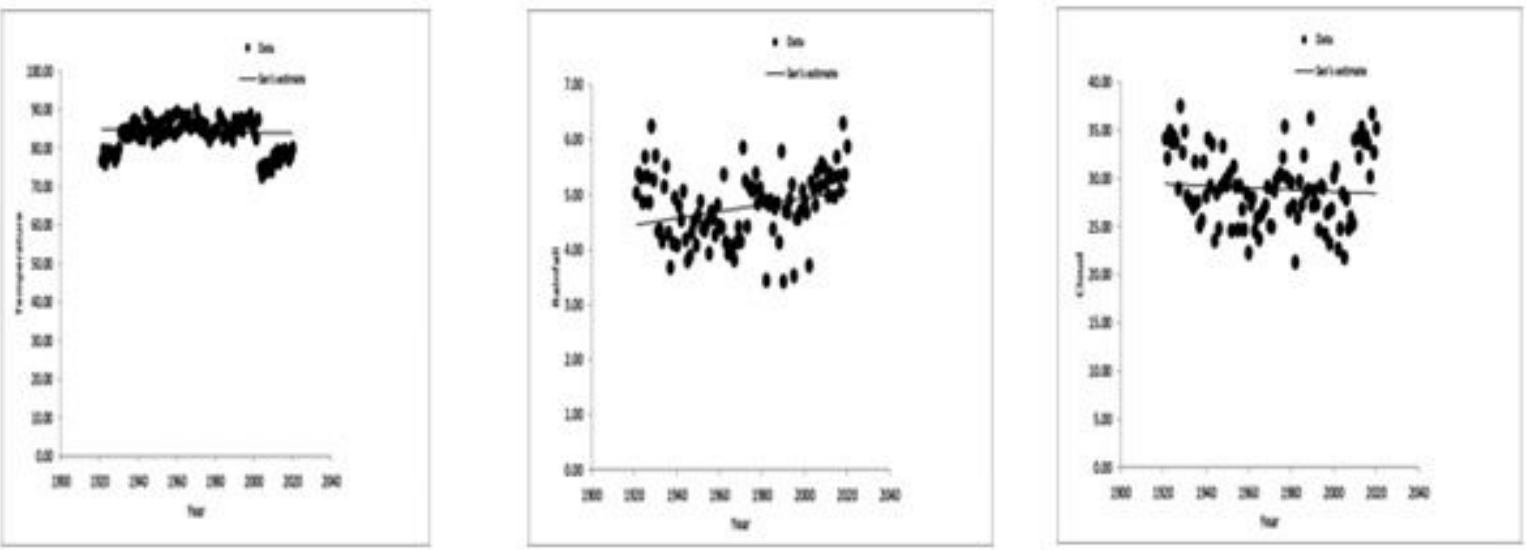

Figure 4

Trend of climatic parameters (temperature, precipitation and cloud fraction) for 100 years

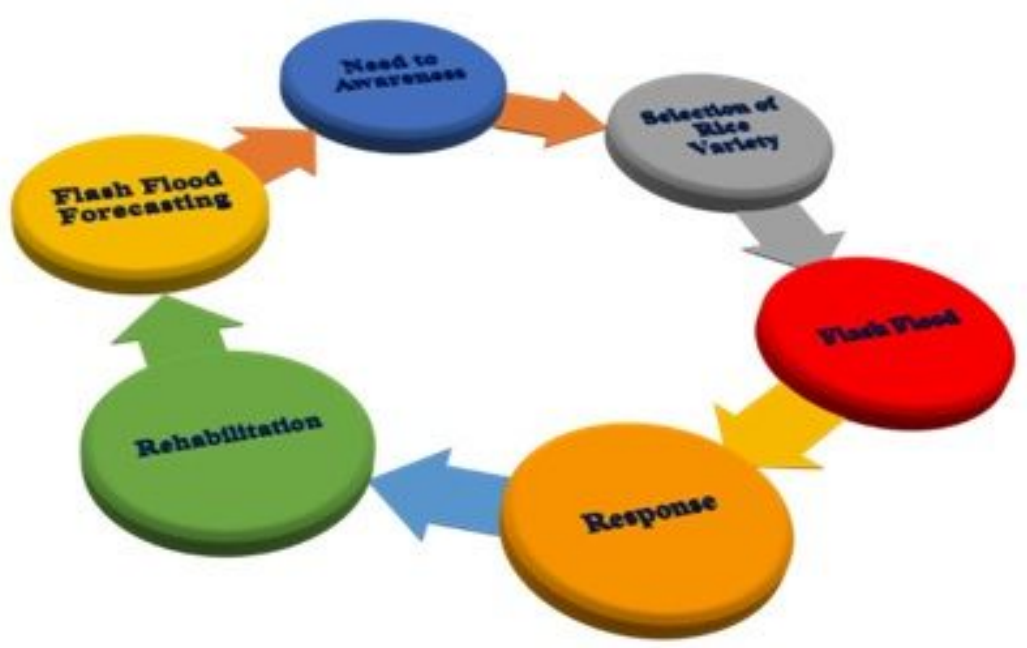

Figure 5

Precautions Strategy Cycle 